Endüstri llişkileri ve Insan Kaynakları Dergisi

Cilt:17 -Sayı:3 -Temmuz 2015

\begin{tabular}{|c|c|c|}
\hline & MAKALE ADI & SAYFA \\
\hline 1 & $\begin{array}{l}\text { SCHAUFELİ VE BAKKER TARAFINDAN GELIŞTİRILMIŞ OLAN İŞE ANGAJE OLMA } \\
\text { ÖLÇEĞİIN TÜRKÇE'DE GÜVENILİRLİK VE GEÇERLILİĞINİN ANALIZİ } \\
\text { PROF.DR. ENVER ÖZKALP-PROF.DR. BİLÇİN MEYDAN } \\
\text { DOI: 10.4026/1303-2860.2015.0285.x }\end{array}$ & 4-19 \\
\hline 2 & $\begin{array}{l}\text { ARAŞTIRMALARDA İSTATİSTIK VE ETIKK } \\
\text { PROF. DR. NURAN BAYRAM } \\
\text { DOI: } 10.4026 / 1303-2860.2015 .0286 . x\end{array}$ & $20-29$ \\
\hline 3 & $\begin{array}{l}\text { LABOUR LAW AWARENESS OF EMPLOYEES: A COMPARISON FROM GERMANY AND } \\
\text { TURKEY } \\
\text { PROF. DR. ÖMER SADULLAH-ASSOC.PROF.DR. FULYA AYDINLI KULAK-MELTEM } \\
\text { SERMET } \\
\text { DOI: } 10.4026 / 1303-2860.2015 .0287 . x\end{array}$ & $30-48$ \\
\hline 4 & $\begin{array}{l}\text { SKILLED WORKFORCE TRAINING PROGRAMS FOR THE TURKISH TEXTILE AND } \\
\text { APPAREL INDUSTRY, CASE OF DENIZLI } \\
\text { ASSOC.PROF.DR.SEMA PALAMUTCU, NEDIM DOĞAN } \\
\text { DOI: 10.4026/1303-2860.2015.0288.X }\end{array}$ & $49-60$ \\
\hline 5 & $\begin{array}{l}\text { DEĞiŞ̧EN İŞ ORTAMINDA BİREYE AİT DİNAMİKLER: ÖZ-DENETİM'İN ROLÜ YARD. DOÇ. } \\
\text { DR. ESRA ATILLA BAL } \\
\text { DOI: 10.4026/1303-2860.2015.0289.X }\end{array}$ & $61-71$ \\
\hline 6 & $\begin{array}{l}\text { ULUSLARARASI TICARETİN ADALETINİ SORGULAMAK: ADİL TİCARET SISTEMİ, } \\
\text { ÇALIŞMA KOŞULLARINA ETKISI VE FINDIK İŞÇILERİ İÇIN “ADALET” ARAYIŞI } \\
\text { YARD.DOÇ.DR.ASLI ŞEN TAŞBAŞI } \\
\text { DOI: 10.4026/1303-2860.2015.0290.X }\end{array}$ & $72-92$ \\
\hline 7 & $\begin{array}{l}\text { KIŞiLİĞE YÖNELİK YILDIRMA (MOBBING) DAVRANIŞLARI ve FİZYOLOJIKK ETKİLER } \\
\text { ARASINDAKİ İLIŞKIDE PSİKOLOJIK ETKİLERİN ARACILIK ROLÜ } \\
\text { YARD. DOÇ. DR. HAKAN SEZEREL, YARD. DOÇ. DR. SEDAT BOSTAN, YARD. DOÇ. DR. } \\
\text { TARHAN OKAN } \\
\text { DOI: 10.4026/1303-2860.2015.0291.X }\end{array}$ & 93-118 \\
\hline 8 & $\begin{array}{l}\text { ETIKSSEL DAVRANIŞLAR VE ETİKSEL İKLİMİN MOBBİNG ÜZERİNDEKİ ETKİSİ: BİR ALAN } \\
\text { ARAŞTIRMASI -DR. FİKRET SÖZBİLIR } \\
\text { DOI: } 10.4026 / 1303-2860.2015 .0292 . X\end{array}$ & $119-140$ \\
\hline 9 & $\begin{array}{l}\text { MAVİ YAKALI ÇALIŞANLAR: NEDEN AKADEMİK ÇALIŞMALAR İÇİN CAZİP BİR } \\
\text { ÖRNEKLEM DEĞIL? } \\
\text { PROF. DR. SERKAN BAYRAKTAROĞLU, DOÇ. DR. YASEMİN ÖZDEMİR, ARŞ. GÖR. } \\
\text { MUSTAFA ARAS, ARŞ. GÖR. SAMET ÖZDEMİR } \\
\text { DOI: 10.4026/1303-2860.2015.0293.X }\end{array}$ & 141-157 \\
\hline 10 & $\begin{array}{l}\text { KARMA ÇALIŞMA ÖLÇEĞINIIN TÜRKÇE FORMUNUN GEÇERLİK VE GÜVENİRLİĞİ } \\
\text { DOÇ.DR.AHMET AKIN , ARŞ.GÖR.MEHMET BAŞÖREN } \\
\text { DOI: 10.4026/1303-2860.2015.0294.X }\end{array}$ & $161-167$ \\
\hline 11 & $\begin{array}{l}\text { GENDER DIFFERENCES IN WORK EXPERIENCES AND WORK AND LEARNING OUTCOMES } \\
\text { AMONG EMPLOYEES IN THE MANUFACTURING SECTOR IN TURKEY: AN EXPLORATORY } \\
\text { STUDY } \\
\text { PROF.DR.RONALD BURKE, PROF.DR.MUSTAFA KOYUNCU, JACOB WOLPIN, } \\
\text { ASST.PROF.DR.FÜSUN TEKIN ACAR, KADIFE KOYUNCU } \\
\text { DOI: } 10.4026 / 1303-2860.2015 .0295 . x\end{array}$ & 168-183 \\
\hline
\end{tabular}




\section{KÜNYE}

İş,Güç, Endüstri İlişkileri ve İnsan Kaynaklar Dergisi, yılda dört kez yayınlanan hakemli, bilimsel elektronik dergidir. Çalışma hayatna ilişkin makalelere yer verilen derginin temel amact, belirlenen alanda akademik gelişime ve paylaşıma katkıda bulunmaktadır. İş, Güç, Endüstri İlişkileri ve İnsan Kaynakları Dergisi, 'Türkçe' ve 'Ingilizce’ olarak iki dilde makale yaymlanmaktadir.

Is,Guc The Jorunal of Industrial Relations and Human Resources is peer-reviewed, quarterly and electronic open sources journal. IsGuc covers all aspects of working life and aims sharing new developments in industrial relations and human resources also adding values on related disciplines. Is, Guc The Jorunal of Industrial Relations and Human Resources is published Turkish or English language.

\section{Editörler Kurulu / Editorial Board}

Aşkan Keser (Uludağ University)

K.Ahmet Sevimli (Uludağ University)

Şenol Baştürk (Uludağ University)

\section{Editör / Editor in Chief}

Şenol Baştürk (Uludağ University)

\section{Yaym Kurulu / Editorial Board}

Doç.Dr.Erdem Cam (ÇASGEM)

Yrd.Doç.Dr.Zerrin Furat (Uludağ University)

Prof.Dr.Aşkın Keser (Uludağ University)

Prof.Dr.Ahmet Selamoğlu (Kocaeli University)

Yrd.Doç.Dr.Ahmet Sevimli (Uludağ University)

Prof.Dr.Abdulkadir Şenkal (Kocaeli University)

Doç.Dr.Gözde Yllmaz (Marmara University)

Yrd.Doç.Dr.Dr.Memet Zencirkuran (Uludağ University)

\section{Uluslararası Danışma Kurulu / International Advisory Board}

Prof.Dr.Ronald Burke (York University-Kanada)

Assoc.Prof.Dr.Glenn Dawes (James Cook University-Avustralya)

Prof.Dr.Jan Dul (Erasmus University-Hollanda)

Prof.Dr.Alev Efendioğlu (University of San Francisco-ABD)

Prof.Dr.Adrian Furnham (University College London-İngiltere)

Prof.Dr.Alan Geare (University of Otago- Yeni Zellanda)

Prof.Dr. Ricky Griffin (TAMU-Texas A\&M University-ABD)

Assoc. Prof. Dr. Diana Lipinskiene (Kaunos University-Litvanya)

Prof.Dr.George Manning (Northern Kentucky University-ABD)

Prof. Dr. William (L.) Murray (University of San Francisco-ABD)

Prof.Dr.Mustafa Özbilgin (Bruner University-UK)

Assoc. Prof. Owen Stanley (James Cook University-Avustralya)

Prof.Dr.Işık Urla Zeytinoğlu (McMaster University-Kanada) 


\section{Ulusal Danışma Kurulu / National Advisory Board}

Prof.Dr.Yusuf Alper (Uludağ University)

Prof.Dr.Serpil Aytaç (Uludağ University)

Prof.Dr.Veysel Bozkurt (İstanbul University)

Prof.Dr.Toker Dereli (Işık University)

Prof.Dr.Nihat Erdoğmuş (İstanbul Şehir University)

Prof.Dr.Ahmet Makal (Ankara University)

Prof.Dr.Ahmet Selamoğlu (Kocaeli University)

Prof.Dr.Nadir Suğur (Anadolu University)

Prof.Dr.Nursel Telman (Maltepe University)

Prof.Dr.Cavide Uyargil (İstanbul University)

Prof.Dr.Engin Ylldirm (Anayasa Mahkemesi)

Doç.Dr.Arzu Wasti (Sabancı University)

\section{Tarandığı Indeksler/Indexes}
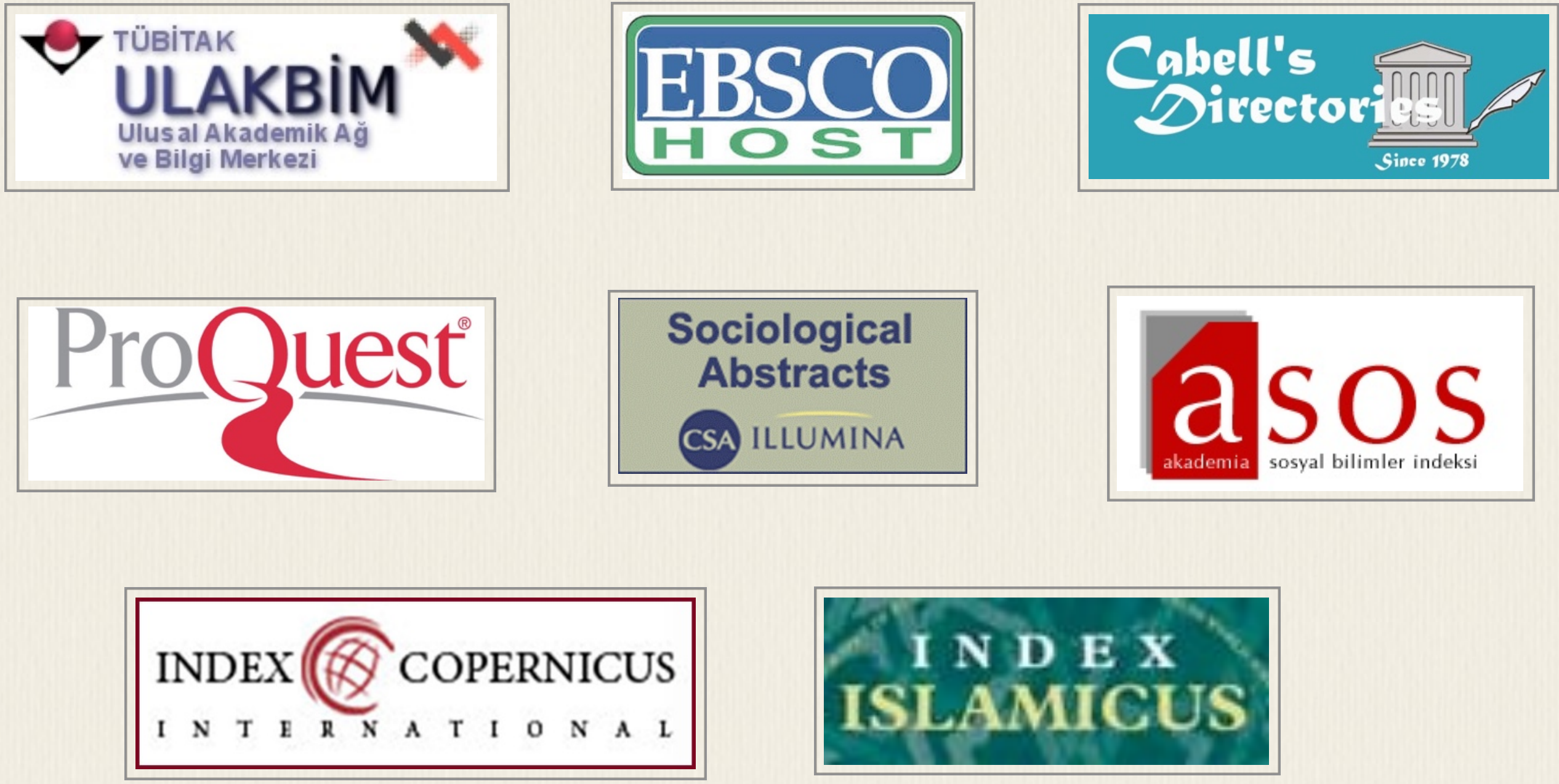

Dergide yayınlanan yazılardaki görüşler ve bu konudaki sorumluluk yazarlarnna aittir. Yayınlanan eserlerde yer alan tüm içerik kaynak gösterilmeden kullanılamaz.

All the opinions written in articles are under responsibilities of the outhors.

The published contents in the articles cannot be used without being cited

“İşGüç” Endüstri İlişkileri ve İnsan Kaynakları Dergisi - (C) 20oo- 2015

"Is,Guc" The Journal of Industrial Relations and Human Resources - (C) 200o- 2015 


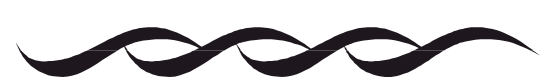

\title{
SKILLED WORKFORCE TRAINING PROGRAMS FOR THE TURKISH TEXTILE AND APPAREL INDUSTRY, CASE OF DENIZLI
}

\author{
Assoc.Prof.Dr.Sema PALAMUTÇU ${ }^{1}$ \\ Pamukkale University, Engineering Faculty, Textile Engineering Department \\ Nedim DOĞAN \\ işKUR-Turkish Labour Organization-Alanya
}

\section{ÖZET}

Tekstil ve hazırgiyim sektörü ülkemizin en önemli imalat sektörleri arasındadır. Yıllık ihracat gelir açısısndan bakıldığında 2014 yılında elde edilen ihracat geliri toplamı 27,6 milyon dolar olup, toplam ülke ihracat geliri için deki payı yaklaşık olarak \%16,5'tur. Sektörde istihdam edilen kişi sayısının gayri resmi rakamlarla iki milyon civarında olduğu tahmin edilmektedir. Sektörün ülkemizdeki büyüklüğü ve önemi ile beraber tekstil ve özellikle hazır giyim sektöründeki yoğun işçilik gereksinimi ülkemizde bu alanda sürekli olarak nitelikli işgücü yetiştirlmesini bir zorunluluk haline getirmektedir. Dünyadaki tekstil imalat makinaları satış rakamları incelendiğinde ülkemizin bu alandaki makina ve üretim yatırımlarının devam etmekte olduğu görülmektedir. Bu durum önümüzdeki yıllarda da bu alanda imalat ve ihracatın sürdürüleceğini; bu üretim kapasitesine bağlı olarak ta nitelikli iş gücü ihtiyacının artarak devam edeceğini göstermektedir.

Sektörün ihtiyaç duyduğu iyi eğitimli, ve nitelikli işgücü kapasitesini karşılamak için ülkemizde akademik ve akademik olmayan eğitim programları yapılandırılmıştır. Bu eğtim programları devlet veya özel sektör girişimleri ile yürütülmektedir. Bu çalışmada Denizli ili çalışan profili kullanılarak ülkemizde konuyla ilgili olarak yürütülen eğitim ve işgücü geliştirme programları analiz edilmiş ve iş gücü kapsamında sektörün sürdürülebilirli hakkında incelem yapılmıştır.

Anahtar kelimeler: Nitelikli İşücü, Eğitim Programları, Türk Tekstil ve Hazır Giyim Sektörü, Denizli

\footnotetext{
${ }^{1}$ Corresponding Author: Sema Palamutcu, E mail: spalamut@pau.edu.tr
} 


\begin{abstract}
Textile and apparel sector is one of the vital sectors in Turkey. Total export revenue of the sector for the year of 2014 is reported as US\$27,6 million which covers about $16,5 \%$ of the Turkey's annual export income. The number of employee of the sector is estimated about 2 million person. As one of the labour intensive sectors, textile and apparel sector constantly requires new skilled and qualified workforce. The annual world textile machinery export reports show that textile machinery investments continue in Turkey, which indicates uninterrupted skilled workforce requirement in the sector.

Well educated and trained workforce demands of the sector is met by academic education and non-academic training programs which are planned and coordinated both by governmental and nongovernmental programs in Turkey. This study is aimed to review and discuss the current textile and apparel sector centered training programs in Turkey from the view point of Denizli employee profile and ongoing training programs.
\end{abstract} Denizli

Keywords: Skilled Workforce, Training Programs, Turkish Textile and Apparel Sector,

\title{
Introduction
}

Textile and apparel sector has been one of the leading manufacturing sectors of Turkey from the view of export income, employment capacity, and economical benefit potential. Industrial sized manufacturing phase of the sector in Turkey has started its accelerated improvement during 1980's, while the sector has already completed its mature periods in most of the developed countries (Karaalp, 2012). Flourishing period for textile and apparel manufacturing sector has started as result of governmental promotions and open foreign market policies in Turkey during 1980's (Atılgan, 2006). Recovery of world textile and apparel supplier gap has been partially commencing by progressing Turkish textile and apparel sector since about 30 years. Currently, annual export volume of Turkish textile and apparel sector in the world markets is about US\$25 billion USD. Manufacturing purposed machinery investment in the sector has reached up to US\$100 billion in integrated and advanced manufacturing technologies and it has still been continuing (Textileworldasia, 2012). Currently, sector is overwhelming other economic turnover of the country and has the dragging effect over the other local business and sectors (IAOSB, 2012). According to the Official State Plans of the Turkey, it has been aimed that in 2023, the 100th anniversary of the founding of the Turkish Republic, annual total export income of the sector should reach about to US\$72 billion (Turkishtime, 2013; bilisim dergisi, 2014; ITKIB report, 2013).

This study is about the governmental vocational training programs that are carried out to meet the skilled workforce needs of continually existing sector in Turkey. In the paper currently implemented sectoral training programs are evaluated and program improvement suggestions discussed, special skilled labour requirements of the sector are 


\section{SKILLED WORKFORCE TRAINING PROGRAMS FOR THE TURKISH TEXTILE AND APPAREL \\ INDUSTRY, CASE OF DENIZLI- \\ ASSOC.PROF.DR.SEMA PALAMUTCU-NEDIM DOĞAN}

analyzed and influence of current labour market implications are reviewed. Reports and statistical data of Turkish Labour Organization (ISKUR) and Denizli Chamber of Industry (DSO) are used to analyze current workforce climate of textile and apparel sector. Arguments and suggestions are revealed using the case study data of Denizli, which is one important cotton textile and apparel manufacturing centers of Turkey, and worldwide known towel production center.

\section{Turkish textile and apparel sector}

The textile and apparel sector is one of the main export fields for Turkey, accounting about 17\% (ITKIB report, 2013) of the export incomes and 12\% (Tekstil, Hazır Giyim, Deri ve Deri Ürünleri Sektörleri Raporu, 2013) of the total employment for the year of 2013. Turkish textile and apparel sector is increasing its export income constantly as it has shown in Figure 1.

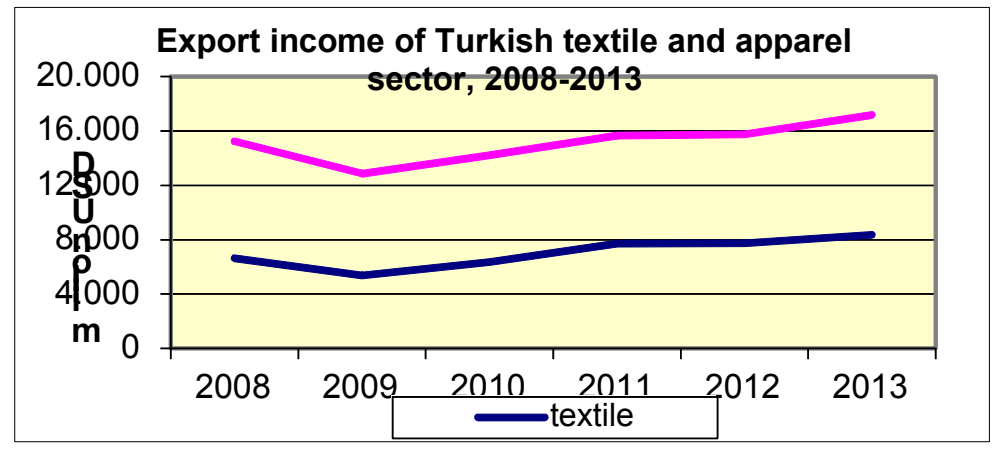

Figure 1. Textile and apparel export income of Turkey for 2008-2013

According to annual report of the General Secretariat of Istanbul Textile and Apparel Exporter Associations (ITKIB) for 2009, there are approximately 7,500 textile manufacturers and 11,000 apparel manufacturers in Turkey producing goods for export (Textileworldasia, 2012). Currently, the number of textile and apparel manufacturer has anticipated stay constant with some narrow fluctuations.

Sector is one of the main export oriented manufacturing sectors of Turkey with derivation of the highest foreign trade surplus. Beside foreign trade income of the sector, domestic consumer market volume of Turkey is also constantly enlarging, to furnish new employment capacities for the sector. Turkish textile and apparel sector remains its competitiveness among other textile and apparel sector dependent developing countries with its unique attributions. Grounds of being a competitive player in the field can be listed as; having qualifying professional and administrative experience of three decades; comparatively lower labour costs; accessibility and geographical proximity to the rising markets; easy access to the raw material markets; favorable business surroundings; and young labour force that willingly to work in the sector. 
As counterpart, there are weaknesses of the Turkish textile and clothing sector, which are lack of branding, lack of technology development, lack of high value addedinnovative products, still in its improvement phase of fashion-design ability, increasing trends of current labour costs. Low wages has no longer be seen as an advantage for Turkish textile and apparel sector, where skilled and well trained workforce gains more emphasis (Atılgan T, 2007).

\section{Textile and apparel sector in Denizli}

Denizli is one of the main cotton textile and apparel manufacturing center of the Turkey. The city has 7000 years of textile history starting from the antique ages and textile manufacturing traditions of the city continue until now. Currently approximately 600 textile and apparel manufacturing companies out of total 2.200 companies are running in the city (Denizli Tekstil Sanayi Envanteri, 2012). Derived added value of the sector is about $50 \%$ of the US\$2,9 billion, which is the total annual export income of Denizli for 2013. Textile and apparel manufacturing sector in Denizli is the most vital sector from the view of its employment capacity, economical income potential, and female employment capacity.

Total employment of the textile and apparel sector in Denizli is reported as $29.735^{2}$ people, out of city's total official employment 60.387 (Figure 2). Female employment rate is lower than the male employment rate both in textile and apparel sector and also in total employment rates. Female employment rate in the Denizli textile and apparel sector is about $86 \%$, where it is only about $48 \%$ for the total employment that implies that the sector has great influence on the women employment capacity(Denizli Tekstil Sanayi Envanteri, 2012).

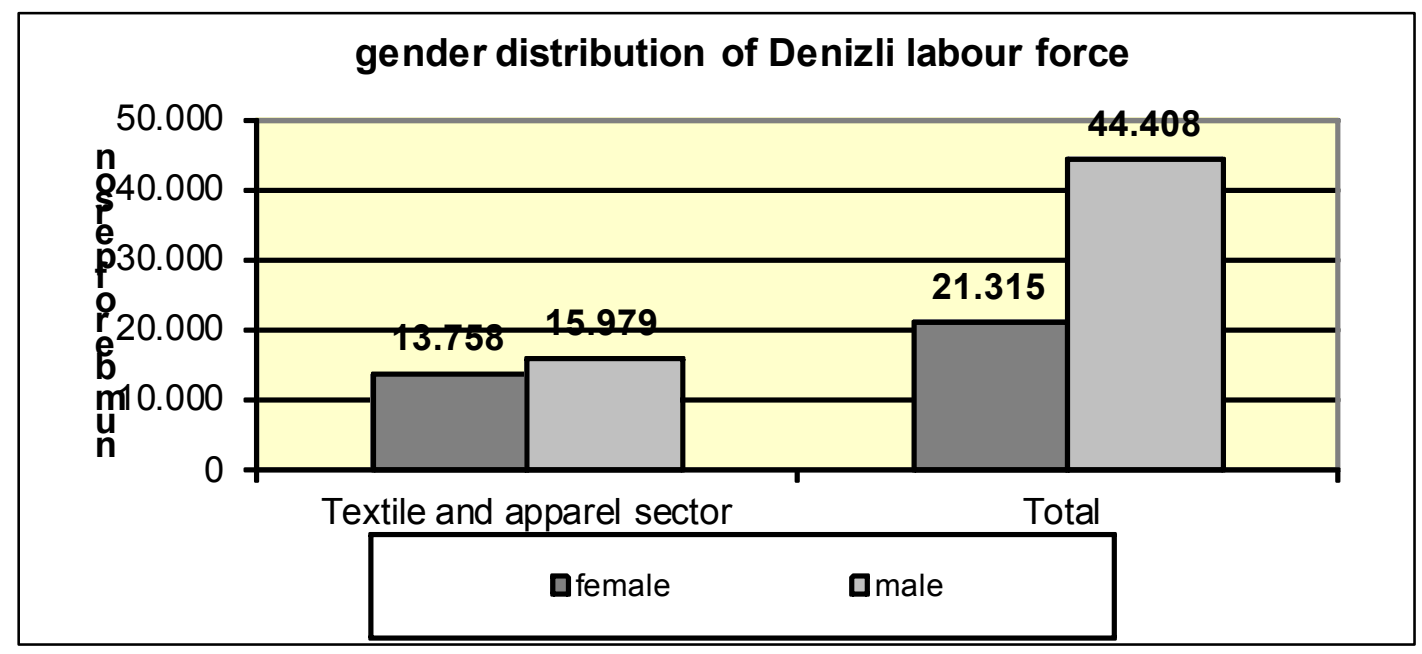

Figure 2. Gender distribution of Denizli labour force

Employment rate of textile and apparel sector in the total employment capacity of Denizli is reported as 26\%, where it is $12 \%$ for Turkey for the year of 2013 (Denizli işKUR iş Piyasası Araştırma Raporu, 2013; DSO rapor, 2009; Tekstil, Hazır Giyim, Deri ve Deri Ürünleri Sektörleri Raporu, 2013). It can be underlined from the given employment rates that every

2 Unofficially, it has been estimated that the total number of textile and apparel related workforce of the city is more than 55.000 (kayıt dışı istihdam, 2013) [11] that corresponds about 10\% the total city center population of about 575.000 (current popuşation reports, 2013) [12]. 


\section{ASSOC.PROF.DR.SEMA PALAMUTCU-NEDIM DOĞAN}

one person out of four is working in the textile and apparel sector in Denizli. According to the official report of Denizli Chamber of Industry (DSO) (

Figure 3), employment rate of the sector has now been stabilized around $26 \%$ of total city employment with some narrow fluctuations.

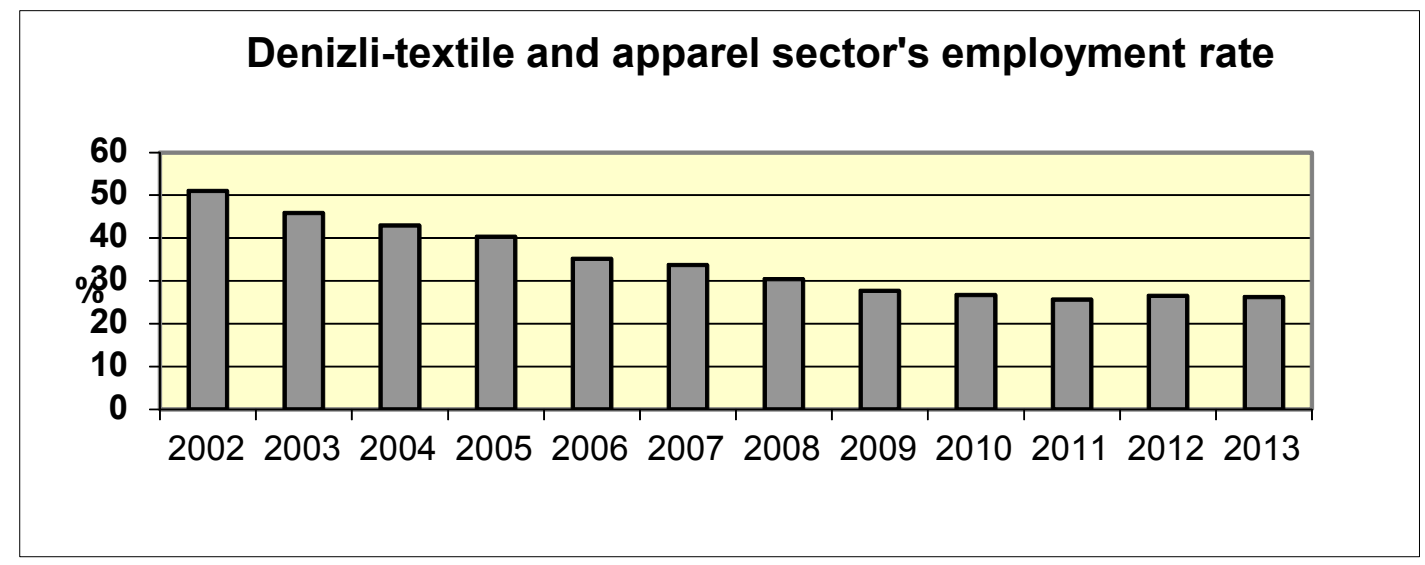

Figure 3 Employment rate change of textile and apparel sector in Denizli, 2002-2013 (DSO rapor, 2009)

According to the textile inventory report of Denizli $85,7 \%$ of the total employee in the Denizli textile and apparel sector is assigned to operate in the production departments of textile and apparel companies (Table 1).

Table 1 Departmental employment allocation in Denizli textile and apparel sector (Denizli Tekstil Sanayi Envanteri, 2012)

\begin{tabular}{|l|r|}
\hline Subdivision of Departments & \multicolumn{1}{|c|}{$\%$} \\
\hline Production & 85,7 \\
\hline Support services(storage, logistics, packing) & 6,0 \\
\hline Account-finance & 3,0 \\
\hline Sale and marketing & 2,6 \\
\hline Planning & 1,5 \\
\hline Human resource & 0,7 \\
\hline Research \& development & 0,5 \\
\hline Total & 100,0 \\
\hline
\end{tabular}

Share of support service and account-finance departments are follows production department and their shares are reported as $6 \%$ and $3 \%$ respectively. Rest of the employee which is about $5 \%$ of total employment are assigned to work in sale and marketing, planning, human resource and R\&D departments (Denizli Tekstil Sanayi Envanteri, 2012).

\section{Sustainable employment policies}

Sustainable development of the textile and apparel sector is vital for Turkish economy, considering its employment capability and product export potential. One of the influential factors effecting the sustainable growth of the sector in the severe international competition is sustainable and accurately trained workforce provision of the employment 
İş,Güç Endüstri iliş̧kileri ve İnsan Kaynakları Dergisi/Is,Guc The Journal of Industrial Relations and Human Resources, Temmuz/July 2015, Cilt/Vol: 17, Sayı/Num: 3, Sayfa/Page:49-60

requirements. According to the sectoral projections, skilled work force demand of the sector will continue as results of sectoral eagerness, consisting renovation of existing firms and new investments in progress. In order to respond to the emerging qualified workforce needs of the sector, accurately targeted education and training programs are executed and improved according to the Bologna declaration.

Textile and apparel sector based educational programs are managed by governmental academic programs of vocational high school, two year technical education programs, and undergraduate and graduate degree programs. Beside the sector based academic programs, non academic training programs are also improved and offered both by governmental and non governmental organizations.

ISKUR that is subdivision of Ministry of Labor and Social Security of Turkey, recruitet with management of active and non-active labour market policies in Turkey. Assigned tasks of ISKUR are conduction of support actions about conservation, improvement and spreading of emloyment among working age population; improvement of correction actions against unemployment, and management of unemployment insurance services over the country's labour environment. Other commitments of the ISKUR are designation of labour demand and supply, work and profession analysis, mentoring, skilled workforce training, integration of workforce and vocational training programs, and placement (Mütevellioğlu, 2010).

Local needs of selected sectors are assessed by operative policies of ISKUR and skilled work force needs of the targeted sector, such as textile and apparel, is responded with a series of carefully designed programs. For the case of Turkish textile and apparel sector, where sustainable occurance and continues improvement are inevitable, ISKUR is the most active policy maker about labour market planning.

\section{Denizli Labour environment}

Textile and apparel sector with the highest competiveness capacity among other manufacturing sectors of the city is the most important sector in Denizli. According to the official reports of the işKUR (Denizli işKUR iş̧ Piyasası Araştırma Raporu, 2013), 51.700 person has been officially active in working life of Denizli manufacturing sectors, which include textile and apparel, food, metal, mine and agricultural occupations.

Employment profile of a population can be defined with some definitive indicators of labour force participation rate, employment rate and unemployment rate, which are shown in Figure 4. Labour force participation rate is one definitive indicator used to explain the employment profile of a population and it is defined as the rate of the working-age (those aged 15 to 65) population, who is either working or actively seeking work, to the total working-age population. For the case of Denizli labour force participation rate is reported as $56,7 \%$, which is higher than Turkey's labour force participation rate of $50,8 \%$ for the year of 2013. Another commonly used indicator is employment rate which is defined as the ratio of total number of employed person to the total population. Employment rate of Denizli is also reported higher than the employment rate of Turkey. Reported unemployment rate of Denizli is 6,9\% lower than the unemployment rate of Turkey which is 9,7\% (Figure 4). 


\section{SKILLED WORKFORCE TRAINING PROGRAMS FOR THE TURKISH TEXTILE AND APPAREL \\ INDUSTRY, CASE OF DENIZLI- \\ ASSOC.PROF.DR.SEMA PALAMUTCU-NEDIM DOĞAN}

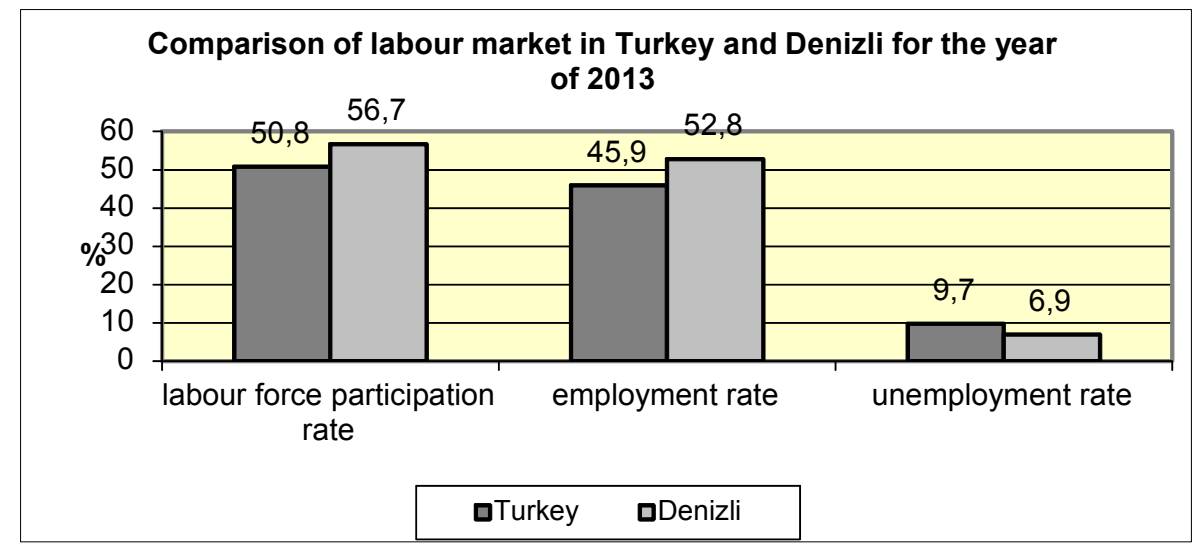

Figure 4. Labour market in Turkey and Denizli, 2013 (Denizli işKUR iş Piyasası Araştırma Raporu, 2013)

Vacancy filling rate is another practical indicator, which is defined as mathematical division of filled vacancy number to the total vacancy number, used to explain the employment profile in a population. According to the monthly data of ISKUR, average annual vacancy filling rates are $51,66 \%$ for Denizli and $46,16 \%$ for Turkey for the year of 2013 (DSO rapor, 2009; Tekstil, Hazır Giyim, Deri ve Deri Ürünleri Sektörleri Raporu, 2013; Mütevellioğlu, 2010).

Above given labour force participation rate, employment rate, unemployment rate, and vacancy filling rate data lead the appearance of a conclusion that the Denizli's labour force environment is more aggressive than Turkey to find, replace and improve new job. It can also be concluded that Denizli labour market is a judicious environment for intensive vocational training programs.

Education level is one of the main influential parameter on the chance of employment. It has been reported for Denizli that labour force participation rate increases with the increasing level of education, which is given in the graphic for the education steps between non-education and higher education (Figure 5).

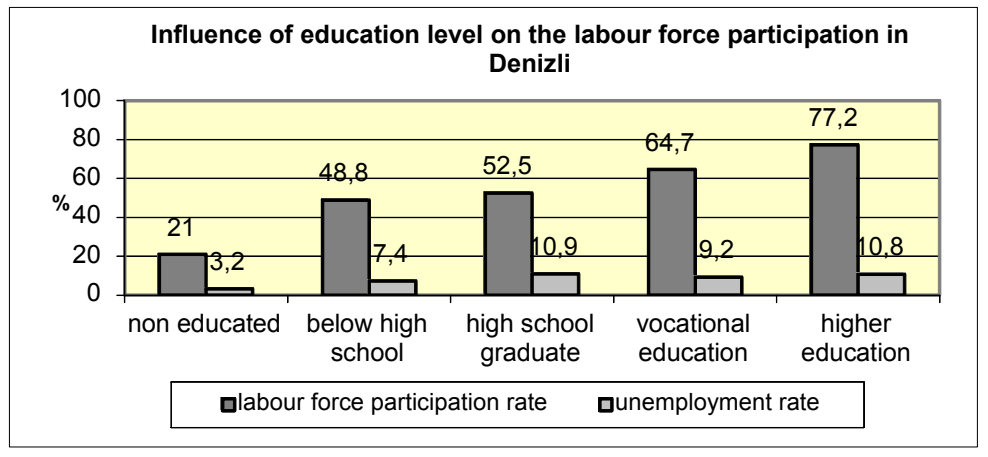

Figure 5. Influence of education level on the employment in Denizli, 2012 (Doğan, 2014) 


\section{Vocational subdivisions in Denizli textile and apparel sector}

According to the local recruited occupation records of Denizli, there are totally 883 different occupations in all sectors, employing 60.387 workers officially. Among the assessed occupations, 85 of them are related to textile and apparel sector employing 29.735 workers in Denizli (Doğan, 2014). Almost half of the employment is realized by the textile and apparel related occupations in Denizli, where the economical and social impact of the sector is definitely important.

\section{Vocational training programs for Denizli textile and apparel sector}

Vocational training is mainly accepted as preparation of employment aged people to any technical or trade based profession. As sort of formal training programs, vocational training programs are planned to give opportunity to the people that either their qualifications are not appropriate to follow a formal academic education programs or their own personal intention. Program curriculum and duration is designated according to the sectoral workforce needs and unemployment report of public authorities or non governmental organizations.

In Table 2, ISKUR structured vocational programs, which are implemented in the frame of active labour market policies, are given for the years of 2010, 2011, and 2012. According to the data, number of implemented vocational programs for textile and apparel sector has increased $32 \%$ where it is $23 \%$ for the other sectors in Denizli. High rate of textile and apparel sector centered training programs eventuate high level of vacancy filling rate in textile and apparel sector.

Table 2 Number of vocational programs implemented in Denizli, 2010-2012 (Doğan, 2014)

\begin{tabular}{|l|c|c|c|c|}
\hline \multirow{2}{*}{} & \multicolumn{3}{|c|}{ Number of training programs } & \% Difference between \\
\cline { 2 - 4 } & $\mathbf{2 0 1 0}$ & $\mathbf{2 0 1 1}$ & $\mathbf{2 0 1 2}$ & $\mathbf{2 0 1 2}$ \\
\hline Textile and apparel sector & 47 & 54 & 62 & 32 \\
\hline Other sectors & 183 & 202 & 221 & 21 \\
\hline TOTAL & 230 & 256 & 283 & 23 \\
\hline
\end{tabular}

Characteristic labour needs of textile and apparel sector has many different occupational diversities. Content and number of vocational training programs are set depending on the sectoral employment statistics and direct demands of the companies.

Table 3 displays the name of implemented programs and number of their run. 
Table 3 Vocational training programs opened for textile and apparel sector in Denizli, 2012 (Doğan, 2014)

\begin{tabular}{|l|c|}
\hline \multicolumn{1}{|c|}{ Name of the program } & $\begin{array}{c}\text { Number of conducted } \\
\text { program }\end{array}$ \\
\hline Sewing machine operator & 23 \\
\hline Socks machine operator & 1 \\
\hline Textile quality control operator & 15 \\
\hline Multi purposed textile and apparel worker & 1 \\
\hline Textile printing machine operator & 1 \\
\hline Textile dye machine operator & 1 \\
\hline Dye house manufacturing operator & 2 \\
\hline Production planning office worker & 8 \\
\hline Fabric packaging operator & 2 \\
\hline Planning and quality control workers & 1 \\
\hline Embroidery worker & 1 \\
\hline Circular knitting machine operator & 1 \\
\hline Apparel manufacturing worker & 1 \\
\hline Marketing office worker & 1 \\
\hline Knitting machine operator & 62 \\
\hline TOTAL & \\
\hline
\end{tabular}

"Sewing machine operator" and "multi purposed textile and apparel worker" programs have the highest number of repeat which pointing the high and continuously demanded skill groups in the Denizli textile and apparel sector. It is also confirmed that the intensity of the sector has been accumulated on the weaving and apparel manufacturing. "Fabric packaging operator" and "textile quality control operator" programs have also repeated several times to respond sectoral workforce needs. Other training programs are only eventuated repeated once or twice that implies either skilled workforce of such operations are not emerging or already fulfilled.

Listed vocational training programs are conducted only on 25 different companies in Denizli where 394 ISKUR registered textile and apparel companies exist out of 526 textile and apparel related companies (Doğan, 2014). Low number of company participation indicates that awareness about the government managed vocational training programs of ISKUR are not high enough in Denizli textile and apparel sector. 


\section{Job placement activities in Denizli}

Job placement term means finding a workplace and defined job to an unemployed person. It is one of the main tasks of iSKUR. According to the official reports of ISKUR, number of job placement has been rising since 2008 in Denizli (Figure 6). In 2013, there have been 12.330 job placement has been succeeded out of 33.599 unemployed person, with the rate of $40,3 \%$. In Denizli every one job placement out of two ( \%64) job placements is comprised in manufacturing sector while it is about one out of three ( \%28) in Turkey. As the main manufacturing sector of Denizli, textile and apparel sector has the highest share in the mentioned job placement rate with the help of consistent training programs.

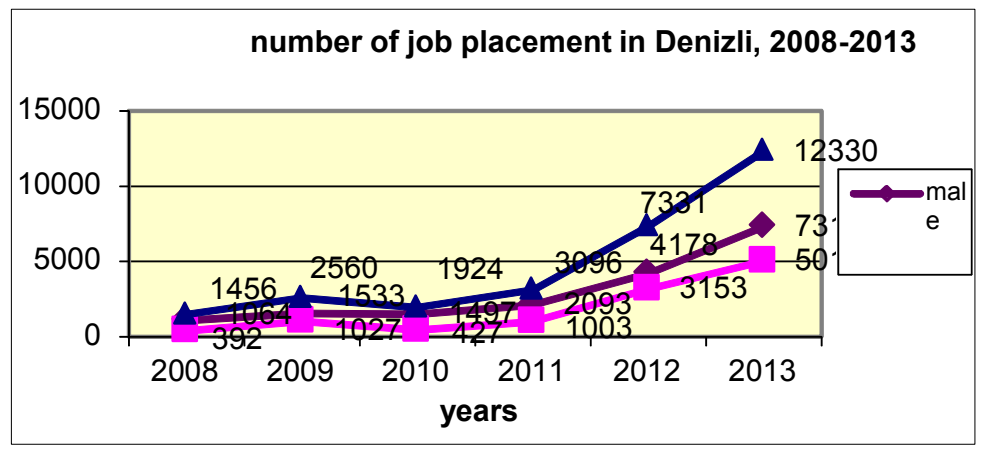

Figure 6. Job placement numbers in Denizli Denizli işKUR İ̧̧ Piyasası Araştırma Raporu, 2013)

\section{Conclusion}

Vocational training programs are one effective instrument to improve sustainable employment policies. Turkish textile and apparel sector, as a labour intensive manufacturing sector, is one unique sector requiring continuously new labour force. Concerning the significant economic and social contributions of sector to the Turkey and to Denizli, supply of sectoral labour force demand is essential. Additionally existence of new generation manufacturing machinery park, stranded and promising know-how, international market conditions should be accepted as encouraging factors for the sustainable existence of Turkish textile and apparel sector.

Sectoral demands are determined using official data of the governmental institutions, reports of local non-governmental organizations and other economic and social indicators. From the view point of Denizli textile and apparel sector, activity reports of ISKUR-local subdivision branch of Ministry of Labour and Social Security of Turkey and inventory report of DSO-Denizli Chamber of Industry are used to analyze the sectoral training employment needs. Below given conclusions can be drawn; 


\section{SKILLED WORKFORCE TRAINING PROGRAMS FOR THE TURKISH TEXTILE AND APPAREL \\ INDUSTRY, CASE OF DENIZLI- \\ ASSOC.PROF.DR.SEMA PALAMUTCU-NEDIM DOĞAN}

-Vocational training programs are main source to respond the labour force requirement of textile and apparel sector in Denizli.

- Labour force absence in textile and apparel sector related occupations are remedied via accurately planned training programs.

-Accurately planned and conducted vocational training programs are resulted with high level of job placement in Denizli. "Sewing machine operator" and "multi purposed textile and apparel worker" training programs have the highest repeat number, and these two jobs are highly demanded jobs in Denizli textile and apparel sector.

-Number of total employment in the sector has increased as result of intensive vocational training programs in Denizli (Figure 4). Beside the vocational training programs, employment increase in Denizli should also be explained as result of the increase in the sectoral production capacity and affirmative surrounding of world market conditions.

-Above implied high vacancy filling rate of Denizli is maintained with the help of increasing number of effectively planned vocational training programs of ISKUR.

-Denizli's labour force environment is more aggressive than Turkey to find, replace and improve new job.

-Women employment level in Denizli is higher than the average of Turkey as result of high employment capability of current apparel sector in Denizli. Vocational training programs should also be improved to sustain and increase woman employment possibility in Denizli and Turkey.

-Given data about number of employed person in Denizli are different from each other. According to the different sources, number of officially employed person in Denizli are mentioned as 51.700 (Denizli işKUR iş Piyasası Araştırma Raporu, 2013) and 60.387 (Doğan, 2014). There are also some other unofficial estimations that Denizli textile and apparel sector employs in total about 55.000 people (kayıt dışı istihdam, 2013) as sum of registered and unregistered employee. Inconsistency about employment data shows that there are some grey color area on the employment data of Denizli working environment in total and also textile and apparel sector. Such uncertainty also implies the urgent need of intensive and close attention to the employment environment of textile and apparel sector.

-Awareness of vocational training programs is not as high as desired, any improvement about the awareness of vocational training programs would positively reflect on the job placement and vacancy filling rate levels of Denizli textile and apparel sector.

\section{REFERENCES}

1- $\quad$ Karaalp HS, Yilmaz ND. Assessment of Trends in the Comparative Advantage and Competitiveness of the Turkish Textile and Clothing Industry in the Enlarged EU Market. FIBRES \& TEXTILES in Eastern Europe 2012; 20, 3(92): 8-11.

2- $\quad$ Atılgan T.,. The Effects of the EU Customs Union with Turkey on the Turkish Textile and Clothing Sector, Fibres \&Textiles in Eastern Europe, 2006; 14, 4(58): 11-15.

3- $\quad$ http://www.textileworldasia.com/Issues/2012/January-FebruaryMarch/Features/Turkey-Prospering Textile And Apparel Industry; access: 08.06.2014 
İş,Güç Endüstri Iliş̧ileri ve İnsan Kaynakları Dergisi/Is,Guc The Journal of Industrial Relations and Human Resources, Temmuz/July 2015, Cilt/Vol: 17, Sayı/Num: 3, Sayfa/Page:49-60 ISSN: 2148-9874, DOI: 10.4026/1303-2860.2015.0288.x

4- $\quad$ IAOSB, Tekstil Ürünleri İmalatı ve Giyim Eşyalarının İmalatı, Temmuz, 2012., http://www.iaosb.org.tr/Media/FileDocument/TEKSTIL\%20VE\%20HAZIR\%20GIYIM\%20SAN AYI\%20TEMMUZ\%202012.pdf, access : 24.06.2014

5- Tekstil ve Hammaddeleri Sektörünün 2023 ihracat Stratejisi, Turkishtime, Temmuz 2013, p.18-25

6- $\quad$ http://www.bilisimdergisi.org/s158/, access: 09.06.2014,

7- $\quad$ Annual foreign trade report of Turkey, textile, apparel, leather and carpet industries, 2013;

http://www.itkib.org.tr/itkib/istatistik/dosyalar/2013/2013 YILLIK GENEL TEK KONF DERI HALI.pdf, access: 24.06.2014

8- Tekstil, Hazır Giyim, Deri ve Deri Ürünleri Sektörleri Raporu, 2013/1

9- $\quad$ Atılgan T., Acceptable Quality Levels in the Textile Sector and their Effect on the Level of Competition, FIBRES \& TEXTILES in Eastern Europe January / March 2007, Vol. 15, No. 1 (60)

10- Denizli Tekstil Sanayi Envanteri, 2012, Report of DENIB-Export Union of Denizli, Pamukkale University

11- Kayıt dışı İstihdam, http://www.isvesosyalguvenlik.com/etiket/kayit-disi-istihdamsigortasiz-isci, access : August 13, 2013

12- Current population reports, http://www.pamukkale.gov.tr/tr/content.asp?id=643

13- Denizli iş̧KUR İş Piyasası Araştırma Raporu, 2013

14- http://www.dso.org.tr/images/file/istatistik/2009/i04.pdf, access : 27.06 .2014

15- Mütevellioğlu, N., Aksoy B., İşsizlikle Mücadelede il İstihdam ve Mesleki Eğitim Kurulları'nın İşlevi, Çalışma ilişkileri Dergisi, 2010, Sayı: 1, S.13-35

16- http://www.indexmundi.com/facts/turkey/labor-participation-rate, access : 01.07.2014

17- Doğan N., Çalışma ve iş Kurumunun Tekstil ve Hazır Giyim Sektörü ile ilgili Faaliyetleri, Denzili ve Tekstil ve Konfeksiyon Sektörünün İncelenmesi, Master Tezi, Pamukakle Üniversitesi Fen Bilimleri Enstitüsü, 2014 